\title{
The Effect of Forest Road on Bank Vole and Yellow-Necked Mouse Populations
}

WPEYW DROGI SRODLESNEJ NA POPULACJE NORNICY RUDEJ I MYSZY LESNEJ

Cezary BĄKOWSKI \& Michal KOZAKIEWICZ

Bąkowski C. \& Kozakiewicz M. 1988: The effect of forest road on bank vole and yellow-necked mouse populations. Acta theriol., 33, $25: 345-353$ [With 1 Table \& 4 Figs]

Movements of bank voles Clethrionomys glareolus (Schreber, 1780) and yellow-necked mice Apodemus flavicollis (Melchior, 1834) across forest road were studied. Bank vole population on both sides of the road was characterized and returns of individuals of this species, experimentally translocated to the other side of the road and into the forest, were analyzed. The studies were carried out with the use of the CMR method, on an area of 1.6 ha situated along the forest road, on both its sides. It was found that the road did not restrict or limit the movement of mice, but it did so in the case of voles. No differences in the density, sex ratio and sexual activity, as well as in the mean body weight for bank voles inhabiting opposite sides of the road were found. The animals which had been translocated into the forest returned to the previous place quicker and in greater numbers than those translocated to the other side of the road. Among the animals returning from the forest, males were predominant at first, then the females. Among those returning from the other side of the road the situation was reversed. It was suggested that restrictions of bank voles movement resulted from the species behaviour rather than the inability to cross the road.

[Department of Zoology and Ecology, Warsaw University, Krakowskie Przedmieście 26/28, 00-927 Warszawa, Poland].

\section{INTRODUCTION}

Every natural population maintains within its boundaries an internal continuity, maintained chiefly by interactions between individuals (e.g. Andrzejewski, 1977; Petrusewicz, 1978). Serious ecological effects, including a division of the population into parts, can result from hindering or even limiting these interactions (e.g. Adamczyk \& Petrusewicz, 1966). The breaking of internal continuity of the population can occur as a result of modifications of the structure of natural environments through human activity leading to the creation of barriers restricting the mobility of animals and simultaneously reducing their numbers (Goszczyński \& Werka, 1979; Andrzejewski, 1983; Kozakiewicz 1983; Mader, 1984 and others). Roads and railroads with intensive traffic would constitute the majority of those barriers (Goszczyński \& Werka, 1979). Papers analysing the ecological effects of isolating a population by roads are rare (Oxley et al., 1974; Mader \& Pauritsch, 1981; Wilkins, 1982; Mader, 1984). 
The aim of this study was an attempt to determine the degree, to which forest road isolates the parts of small rodents populations inhabiting areas on both sides of the road. The authors also tried to determine the reasons for this isolation and its ecological effects.

\section{STUDY AREA, METHODS, MATERIAL}

The studies were carried out in August 1985 in the vicinity of Urwitalt near Mikolajki (N-W Poland - N $53^{\circ} 48^{\prime}$ E $21^{\circ} 34^{\prime}$ ) in a study area situated on both sides of a $5 \mathrm{~m}$ wide gravel forest road with an average day-time traffic intensity of 3 vehicles per hour during the study period. Ditches $1 \mathrm{~m}$ deep and $3.5 \mathrm{~m}$ wide ran on both sides of the road. The forest, aged 120-150 years on both sides of the road, had a mixed character with Pinus silvestris L. predominating. In the shrub layer Corylus avellana L., Sorbus aucuparia L. and Evonymus verrucosa Scop. predominated whereas Fragaria vesca L., Hepatica nobilis Garsault and Oxalis acetosella L. constituted the majority in the herb layer.

Eight lines of live traps (4 lines on each side of the road) were used in the study area measuring $200 \times 80 \mathrm{~m}(1.6 \mathrm{ha})$. The traps were placed $10 \mathrm{~m}$ apart and -formed a grid $10 \times 10 \mathrm{~m}$. The trap lines closest to the road were situated in the ditches, the distance between them remaining $10 \mathrm{~m}$ including the width of the road (Fig. 1).

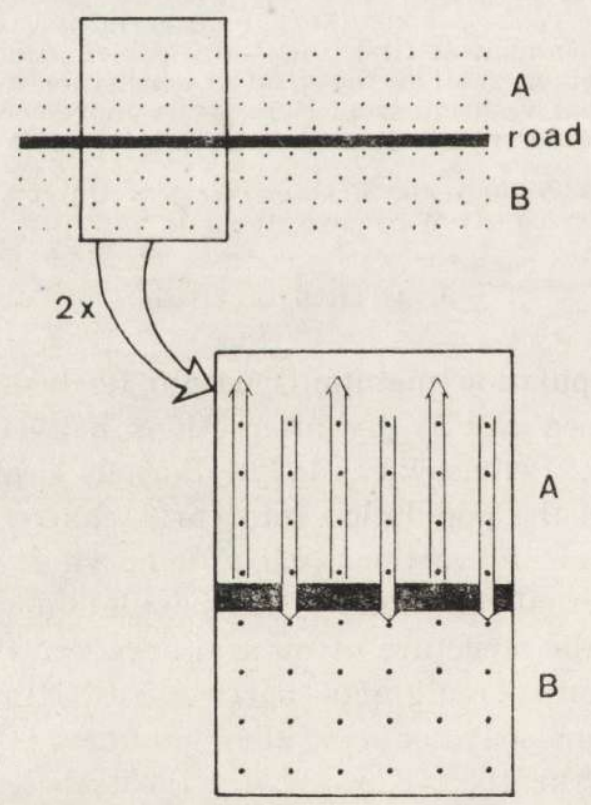

Fig. 1. Plan of the study area; a diagram of the experiment (enlarged fragment). Dots show location bf traps. Arrows on the diagram represent directions of transfers and places of release of animals. A, B - parts of study area on sides $\mathrm{A}$ and $\mathrm{B}$ of the road respectively. 
The CMR method was applied. Oat grain was used as bait. The traps were checked twice a day, in the morning and evening. Each animal caught was given an individual number and species, sex, sexual activity and the place in which it was caught were recorded. The weight of the animals was read from dynamometric scales with accuracy to $1 \mathrm{~g}$. Sexually active were the males with distinctly enlarged testes and females which were pregnant, lactating or with perforated vagina.

The studies were done in two stages. In the first stage lasting 10 days, the catches were made in order to characterize the community of small rodents and the population of the species predominant on either side of the road and to determine the intensity of movement within the study area (including movement accross the road). In the second stage, lasting for 7 days, which was carried out on the half of the study area situated on side A of the road an experiment was conducted, consisting in translocation of the caught individuals to an area not previously occupied by them, setting them free, and analysing their returns (Fig. 1). Meanwhile catches on the other half of the area (side B of the road) were made as in stage 1 . The individuals caught on side $\mathrm{A}$ of the road were translocated either into the forest, $10 \mathrm{~m}$ from the last line of the traps (i.e. $10 \mathrm{~m}$ from the boundary of study area A), or to side B of the road, where they were set free also $10 \mathrm{~m}$ from study area A's boundary (Fig. 1).

The experiment was conducted to compare the rate of returns of the individuals translocated to the other side of the road and into the forest and to attempt to characterize the individuals returning in various times from their transfers. The statistical significance of the differences was determined by $t$-Student test $(p=0.05)$.

A total of 1627 catches of 276 different individuals was achieved. The species were: Clethrionomys glareolus (Schreber, 1780) - 226 individuals, Apodemus flavicollis (Melchior, 1834) - 46 individuals, and occasionally only in the second stage, Apodemus agrarius (Pallas, 1771), Mus musculus (Linnaeus, 1758) and Microtus agrestis (Linnaeus, 1761). Only the results concerning bank voles which predominated, were subjected to a detailed analysis. The individuals of this species exclusively were translocated (a total of 77 individuals).

\section{RESULTS}

\subsection{Desceription of Small Rodents Community and of Bank Vole Population}

The ratios of bank voles numbers to yellow-necked mice numbers were similar on both sides of the road. The bank voles density on sides A and B was 63 and 58 individuals/ha, respectively. In the case of yellownecked mice it was 10 and 9 individuals/ha, respectively. Among bank voles males predominated. Their percentage amounted to $63 \%$ of the population on side A of the road and $68 \%$ on side B $(p>0.05)$. Sexually active males constituted $20 \%$ of the population on side A and $29 \%$ on side $B$, whereas sexually active females accounted for $31 \%$ and $39 \%$ on sides A and B respectively (all differences not significant, $p>0.05$ ).

In analysing the weight of caught individuals pregnant females were not taken into account. No statistically significant differences were found in the average body weight of bank voles caught on both sides of the road $(p>0.02)$ (Table 1$)$. 
Table 1

Average body mass ( $g$ ) of bank voles caught on the two sides ( $A$ and $B$ ) of the road at the first stage of the study.

\begin{tabular}{lcc}
\hline $\begin{array}{c}\text { Category } \\
\text { of individuals }\end{array}$ & Side A & Side B \\
\hline Males: & & \\
Active & 22.6 & 22.4 \\
Non-active & 15.1 & 15.3 \\
Total & 16.5 & 17.7 \\
Fmales: & & \\
Active & 23.4 & 21.7 \\
Non-active & 16.1 & 15.4 \\
Total & 17.6 & 17.3 \\
& & \\
\end{tabular}

3.2. Analysis of Rodents Movement within the Study Area

Movement of bank vole and yellow-necked mouse individuals in a direction perpendicular to the axis of the road between every two neighbouring lines of traps was analysed. This included movement accross the road. Movement parallel to the trap lines was not analysed.

The number of passes of yellow-necked mice between every two neighbouring lines of traps was similar. The number of passes accross the road was not observed to be smaller than between the other lines (Fig. 2). The movement intensity of bank voles was visibly higher than of yellownecked mice. The bank vole individuals made a similar number of passes between neighbouring lines of traps on either side of the road, the number being considerably higher than that of passes accross the road

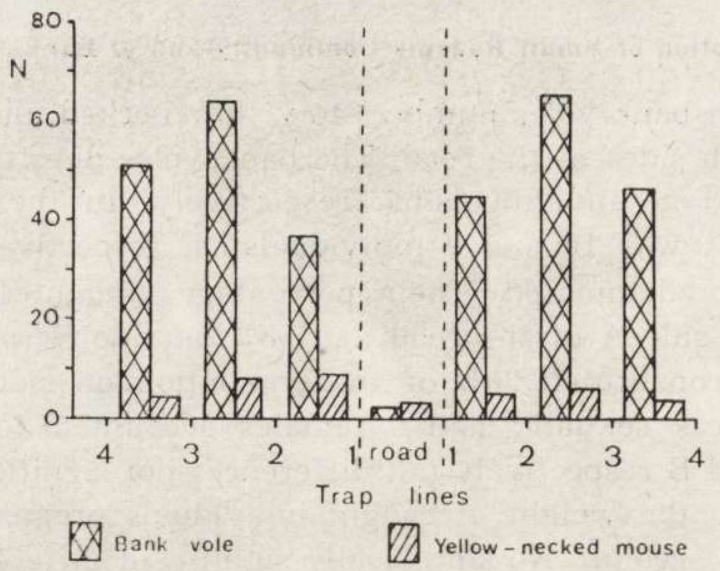

Fig. 2. Number of passes of bank voles and yellow-necked mice between neighbouring lines of traps. 
(Fig. 2). The average number of passes per individual between the two road side lines of traps was significantly statistically lower than the average for other pairs of neigbouring trap lines $(0.05>p>0.02)$.

\subsection{Analysis of Returns of Individuals Translocated and Description of Returning Individuals}

From the bank voles translocated 37 were taken into the forest and 40 to the other side of the road. Crossings of the road made by individuals not translocated were not observed. One time, return passes in the direction of the place, from which the transfers were executed were only recorded.

During the experiment most of the individuals translocated into the forest and $83 \%$ of those taken to the other side of the road returned (Fig. 3). The percentage of returns from the forest was, particularly in the first day of the experiment, considerably higher than that of returns from accross the road $(0.05>p>0.02)$ (Fig. 3).

All returning individuals were divided into two groups. Group one (earlier returns) consisted of the first $40 \%$ of returning individuals i.e. percentage of individuals that returned from the forest before the first check of the traps after the transfer, whereas group two (later returns) comprised the remaining individuals. The time of return of individuals from group 1 translocated into the forest (12 hours from transfer) was $1 / 3$ the time of return from accross the road of individuals from the same group (Fig. 3).

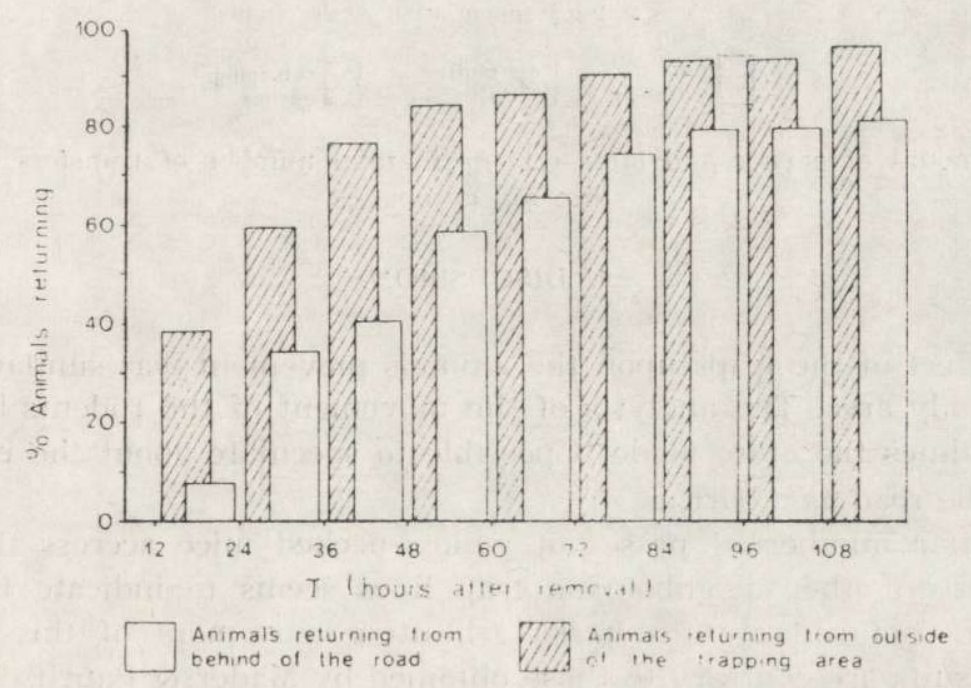

Fig. 3. Total percentage of returns of all individuals of bank voles. 
Over $90 \%$ of the males and females transferred into the forest returned. Equal numbers of males returned, both in group 1 and 2. The majority of the females returned later, however (group 2) (Fig. 4). Individuals returning from both groups showed no significant differences in average body weight $(p>0.05)$.

From the individuals transferred to the other side of the road over $90 \%$ females and $75 \%$ males returned. This difference is not significant $(p>0.05)$. Fewer males returned in group 2 than in group 1 . The females, similarly to those taken into the forest returned mainly in group 2 (Fig. 4). No significant differences in average body weight of individuals in both groups were observed $(p>0.05)$.

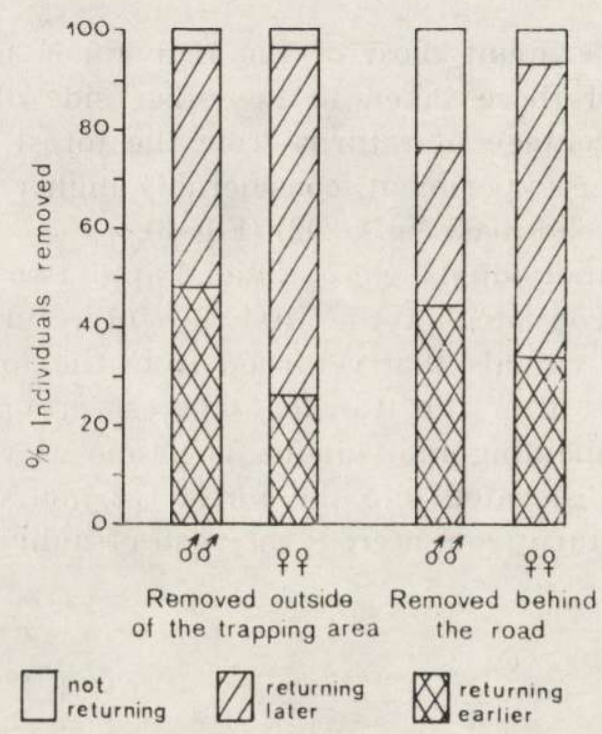

Fig. 4. Amount of earlier and later returns in total number of transfers. Division into sex groups.

\section{DISCUSSION}

The effect of the traps upon the animals movement was similar in the whole study area. The analysis of the movement of the rodents between the trap lines therefore made it possible to speculate about the probable role of the road as a barrier.

A similar number of passes of yellow-necked mice accross the road and between other neighbouring trap lines seems to indicate that the road does not constitute a barrier, limiting movement of this species. These results are contrary to those obtained by Mader \& Pauritsch (1981) and Mader (1984) who observed a visible limitation of movement accross 
roads of yellow-necked mice. They, however, carried out their studies on wide highways with intensive traffic, which could prove to be a barrier even to yellow-necked mouse - a species characterized by large mobility and range of penetration of individuals (Andrzejewski \& Olszewski, 1963; Goszczyński, 1970; Wolton \& Flowerdew, 1984).

A considerably lower number of passes of bank voles accross the road as compared with that of passes between other neighbouring lines of traps seems to indicate, that for this species the road can constitute a barrier limiting its movement. Therefore it can isolate parts of the population on either of its sides.

According to Mazurkiewicz (1978) bank voles are characterized by a high degree of sedentariness. This feature of bank voles was applied in the experiment. Individuals translocated to the other side of the road were expected to be compelled to return to their individual home ranges and-in doing this to cross the barrier of the road. The return migration of approximately $80 \%$ of the translocated individuals proves that the barrier can be crossed. Almost all females returned irregardless of the direction of their transfers, the males, however, returned in almost $100 \%$ only from the forest (no barrier to cross). Those differences seem to be caused by the females' higher degree of sedentariness resulting in a stronger attachment to their individual home ranges (e.g. Zejda \& Pelikán, 1969; Aristova, 1970 and others).

The considerably shorter time of return of the individuals taken into the forest can be explained in two ways: (1) the majority of the bank voles taken deeper into the forest still remained within their individual ranges not needing, thus, to search for them; (2) the translocated individuals could have found themselves outside their individual ranges but returend earlier not encountering a barrier on their way back. Meanwhile the individuals translocated to the other side of the road, found themselves in an unknown habitat and faced the road barring the way back to their own habitats.

As there was an almost total lack of crossings the road of bank voles during the first stage of the study and as the individual which returned back acrcss the road did so in longer time comparing to those ones translocated in the forest, it can be assumed that it is the behaviour of the species and not a lack of possibility, which prevented individuals of this species from crossing the road. It seems that the road, an open terrain without any cover, is deterrent for bank voles and perhaps for other rodents as well (Oxley et al., 1974). Goszczyński \& Werka (1979) point out that small animals show a tendency to situate their home ranges on one side of a barrier only. Therefore as individual home range did not encroach upon the road, they were thus not adjacent and 
the road isolated them, indeed. So it can be assumed that the few registered passes accross the road were made either by dispersers i.e. individuals not having their own home ranges or by individuals on excursions outside their home ranges. These excursions, according to Maza et al. (1973) occur mainly in the reproductive season (when the research was done).

It may well be that intensive movement of the animals accross the road also occured in other seasons, not studied. The experiment, however, was carried out in August when bank vole populations were numerous. Because the intensity of dispersion of this species can grow togeher with the growth of the population (Kozakiewicz, 1976), it was expected during the study period. Movement accross the road in periods of lower population density is probably much less intensive.

Despite the limitation of small rodents movement, caused by the road as an artificial barrier, no major differences were found in population density, sex ratio, sexual activity and average body weight of individuals of the bank voles inhabiting either side of the road. It seems that this could be caused by a similar habitat conditions on either side of the road. It may well be, however, that this two parts of bank vole population did differ, but if so, it was in features which were not studied. Sikorski \& Bernshtein (1984) showed for example, that parts of populations of this species, inhabiting territories on either side of a road did differ as certain non-metric dental and cranial features were concerned.

\section{REFERENCES}

Adamczyk K. \& Petrusewicz K., 1966: Dynamics, diversity and intrapopulation differentiation of a free-living population of house mouse. Ekol. pol. A, 14: 725740. - Andrzejewski R., 1977: Population as an ecological system. Wiad. ekol., 23: 3-33 [In Polish with English summary]. - Andrzejewski R., 1983: Searching for the theory of physiocenosis. Wiad. ekol., 29: 93-125 [In Polish with English summary]. - Andrzejewski R. \& Olszewski J., 1963: Social behaviour and interspecific relations in Apodemus flavicollis (Melchior, 1834) and Clethrionomys glareolus (Schreber, 1780). Acta theriol., 7: 155-168. - Aristova V. A., 1970: Osobiennosti ispolzovanija teritorii krasnoj polevki v lesah južnoj časti Kirovskoj oblasti. Fauna i ekologia gryzunov, 9: 151-159. - Goszczyński J., 1970: Penetration of an area by small forest rodents. Acta theriol., 15: 209-222. - Goszczyński J. \& Werka J., 1979: Wplyw zabudowy i infrastrukutry technicznej na przemieszczanie się fauny. Czlow. Srodow., 3 (1-2): 54-64. - Kozakiewicz M., 1976: Migratory tendencies in population of bank voles and description of migrants. Acta theriol., 21: 321-338. - Kozakiewicz M., 1983: Environmental and ecological effects of the artificial division of the population area. [In: "Environment and population: problem of adaptation". J. B. Calhoun ed.]. Praeger Publ. 22-23. New York. Mader H. J., 1984: Animal habitat isolation by roads and agricultural fields. Biol. Conserv., 29: 81-96. - Mader H. J. \& Pauritsch G., 1981: Nachweis des BarriereEffekts vonverkehrsarmen Strassen und Forstwegen auf Kleinsauger der Waldbiozonose durch Markierungs- und Umsetzungversuche. Natur. Landschaft, 56: 451-454. - Maza B. G., French N. R. \& Aschwanden A. P., 1973: Home range 
dynamics in a popliation of heteromyid rodents. J. Mamm., 54: 405-425. - Mazurkiewicz M., 1978: Spatial organization of the population of small rodents (on the example of bank vole, Clethrionomys glareolus Schreber 1780). Wiad. ekol., 24: 377-390 [In Polish with English summary]. - Oxley D. J., Fenton M. B. \& Carmody G. R., 1974: The effects of roads on populations of small mammals. J. appl. Ecol., 11: 51-59. - Petrusewicz K., 1978: Osobnik, populacja, gatunek. Państw. Wyd Nauk: 1-384. Warszawa - Sikorski M. D. \& Bernshtein A. D. 1984 : Geographical and intrapopulation divergence in Clethrionomys glareolus. Acta theriol., 29: 219-230. - Wilkins K. T., 1982: Highways as barriers to rodent dispersal. Southwest. Naturalist, 27: 459-460. - Wolton R. J. \& Flowerdew J. R. 1984: Spatial distribution and movements of wood mice, yellow-necked mice and bank voles. [In: "Proc. Symp. on the ecology of bank voles and wood mice"]. The Zoological Society of London and The Mammal Society: 12-13. London. Zejda J. \& Pelikán J., 1969: Movement and home range of some rodents in lowland forests. Zool. Listy, 18: 146-162.

Received 10 March 1987, Accepted 19 October 1987. 